NBER WORKING PAPER SERIES

INTERNATIONAL MONETARY INSTABILITY BETWEEN THE WARS:

STRUCTURAL FLAWS OR MISGUIDED POLICIES?

Barry Eichengreen

Working Paper No. 3124

\author{
NATIONAL BUREAU OF ECONOMIC RESEARCH \\ 1050 Massachusetts Avenue \\ Cambridge, MA 02138 \\ September 1989
}

Prepared for the Fourth International Conference of the Institute for Monetary and Economic Studies of the Bank of Japan, May 30-June 1, 1989. I thank Yeongseop Rhee and Carolyn Werley for advice and assistance, and Jeffrey Frankel, Michael Bordo and Bronwyn Hall for helpful comments. This paper is part of a larger research project, supported in part by grants from the German Marshall Fund, the National science Foundation and the Institute of Business and Economic Research of the University of California at Berkeley. This paper is part of NBER's research program in International Studies. Any opinions expressed are those of the author not those of the National Bureau of Economic Research. 
NBER Working Paper \#3124

September 1989

\title{
INTERNATIONAL MONETARY INSTABILITY BETWEEN THE WARS: STRUCTURAL FLAWS OR MISGUIDED POLICIES?
}

\begin{abstract}
This paper reasseses the history of the international monetary system between the wars. It confirms the generality of several widely held interpretations of recent experience with floating exchange rates. There is a positive association between nominal exchange rate flexibility and nominal exchange rate variability. There is a positive asecciation between nominal exchange rate variability and real exchange rate variability. But policies of intervention which reduce nominal exchange rate variability do not guarantee a proportionate reduction in nominal exchange rate risk or in real exchange rate variability and unpredictability. A credible commitment to a stable intervention rule is needed to deliver these benefits.

The paper then goes on to consider four potential explanations for the collapse of the fixed rate regime that prevailed from 1926 through 1931: (1) failure to piay by the "rules of the game," (2) inadequate international economic leadership by the United States, (3) inadequnte cooperation among the leading gold standard countries, and (4) structural features of a system in which reserves were comprised of both goid and foreign exchange. It concludes by assessing the role of the international monetary system in the Great Depression.
\end{abstract}

\author{
Barry Eichengreen \\ Department of Economics \\ University of California \\ Berkeley, CA 94720
}




\section{Introduction}

The interwar period provides a natural laboratory for the study of exchange rate systems. It divides into three distinct regimes: freely floating exchange rates from 1921 through 1926, fixed rates from 1927 through 1931, and managed floating for the remainder of the 1930s. The rapid succession of regimes provides a singular opportunity to assess the implications for asset and commodity markets of different exchange rate arrangements.

Not just the operation of the successive regimes but the transitions between them are of interest. The collapse of the laboriously reconstructed fixed-rate system of the $1920 \mathrm{~s}$ coincided with the spread of the Great Depression. An obvious question concems the causal connection between the two events. Was the Depression responsible for the collapse of the exchange rate system, and if so through what channels was its destabilizing influence transmitted? Alternatively, should the operation of the international monetary system be held responsible, in part at least, for the severity of the Depression?

In this paper I reassess the history of the international monetary system between the wars. Like the history of the period, the discussion is best divided into several parts. As background for what follows, I start in Section 2 with an overview of international monetary relations in the 1920 s and 1930s. Section 3 then provides evidence on the implications for the operation of asset and commodity markets of alternative nominal exchange rate arrangements. In Section 4, I consider explanations for the collapse of the fixed-exchange rate system of the period 1927-31. Was that collapse the result of flaws in the structure of the fixed-rate system or of misguided national economic policies? What was the role of the Great Depression in the system's disintegration? In Section 5, I turn the question around and explore the role of the international monetary system in the Great Depression. Was the operation of the fixed-rate system, its collapse, or both, responsible for the severity of the macroeconomic crisis? This is followed by a brief conclusion and summary of implications. 


\section{An Overview of Interwar Experience}

The classical gold standand provided the framework for international monetary relations in the decades preceding World War I. That system of fixed exchange rates collapsed abruptly with the outbreak of hostilities. The convertibility of currencies into gold was suspended.1/ Monetary and fiscal policies were detached from exchange rate targets and subsumed to the war effort. But wartime exchange rates neither exhibited the volatility they were to display subsequently nor diverged to the same extent as national price levels. Frequently exchange controls were adopted to minimize the fluctuation of nominal rates. Where markets were allowed to operate, currency prices were heavily influenced by government intervention, notably support operations conducted by the United States on behalf of Britain and France.

With the conclusion of hostilities, these support operations were terminated.

Exchange controls were relaxed gradually. Exchange rates began to float freely and were subjected to competing pressures. International inflation differentials having greatly exceeded nominal exchange rate movements, currencies which had depreciated were still overvalued, while those which had not were undervalued. Given prevailing price levels, further exchange rate changes were required to restore long-run competitive balance. But there was no reason to assume that current prices would continue to prevail. National authorities were universally committed to restoring prices to prewar levels and returning exchange rates to prewar parities. So long as this commitment was credible, weak exchange rates would be bid up in anticipation of their eventual revaluation. If, however, the official commitment to strengthening weak exchange rates was not regarded as credible, this mechanism would not operate. So long as budgets remained in deficit and monetary expansion remained the rule, inflation rather than deflation would be in the offing. In this case the logical expectation would be depreciation, not appreciation.

Between 1921 and 1926, exchange rates fluctuated in response to these pressures. A notable feature of this episode is that spot and forward rates were determined in the foreign exchange market subject to a minimum of government intervention. Governments, as a rule, did not intrude directly in the foreign exchange markets. Exceptions, such as France in 1923-24 and 1925-26 and Germany during her hyperinflation, were few. Thus, the early 1920 s provide a relatively pure example of a freely floating exchange rate regime. This is not to deny that fiscal and monetary 
policies could be altered in response to movements in the exchange rate. The point is that governments rarely intervened in the foreign exchange market to damp its response to these changes in policy.

The behavior of exchange rates during this period remains controversial. The standard account (Nurkse, 1944) emphasizes the volatility of nominal exchange rates, attributing it to destabilizing speculation. The classic rebuttal (Friedman, 1953) challenges each element of the standard characterization.

In the middle years of the decade, fixed exchange rates were restored. Among the first countries to do so were those which had endured hyperinflation. In Austria, Germany and Hungary, price-cost disparities were eliminated by the disappearance of nominal contracting and the adoption of currency reform. The task of balancing the budget was simplified by the inflation-induced erosion of the public debt. Opposition to tax increases and public expenditure cuts was overwhelmed by the trauma of uncontrolled inflation. Perhaps most importantly, a fixed exchange rate was seen as a necessary concomitant of successful stabilization. The exchange rate was pegged by Austria in 1923, Germany in 1924 and Hungary in 1925. Other countries which had experienced more moderate inflations soon followed: Belgium in 1925, France in 1926 and Italy in 1927 all returned to gold at somewhat devalued rates.2/ Adjustment was generally more protracted, if less dramatic, in countries attempting to reduce prices and costs in order to restore the prewar gold parity and the traditional dollar exchange rate. Of the industrial countries, Sweden was first to complete the process in 1924. Britain's stabilization in 1925 prompted similar actions by Australia, the Netherlands, Switzerland, South Africa and others. Four countries followed in 1926. By the end of 1927 the transition to fixed exchange rates was largely complete.

The new fixed exchange rate regime was a gold exchange standard, a variant of the prewar system. Gold coin no longer circulated internally, but citizens were entitled to convert domestic currency in excess of certain minimum amounts into ingots of gold. Gold imports and exports were unrestricted. Central banks, with few exceptions, were authorized by national statute to hold a portion of their backing for liabilities in convertible foreign assets rather than gold. The principal reserve currency countries, the United States and Britain, continued to hold mainly gold, while other central banks held a portion of their international reserves in the form of claims on London and New York. The same practice had been followed before World War I, with two notable differences. 
First, it had been neither so widespread or nor so formal. Relatively few central banks had been permitted to hold their official cover in the form of foreign exchange, although their excess reserves often took the form of interest-bearing foreign assets. Second, the currency diversification of foreign exchange reserves had not been so pronounced.

Before the war, sterling accounted for fully half of the foreign currency reserves of central banks 3 / Now, as a result of the war the dollar had emerged as a full-fledged competitor with sterling for the mantle of leading reserve currency. But neither sterling nor the dollar accounted alone for a majority of the foreign exchange holdings of central banks.

If France's de facto stabilization in December 1926 is taken to mark the advent of this system and Britain's devaluation in September 1931 is taken to mark its demise, this new fixed rate regime survived for less than five full years. Even prior to its demise, its operation was viewed as unsatisfactory. The adjustment mechanism seemed inadequate. Some countries like Britain were saddled with persistently weak balances of payments and hemorrhaged reserves for much of the period. Others like France and the United States were in persistent surplus. The adjustments in asset and commodity markets that were supposed to restore external balance did not seem to operate. The management of international liquidity seemed inadequate. The supply of reserves declined precipitously in 1931, as central banks scrambled to liquidate their foreign deposits and the flow of new gold into their coffers was slow to respond to the rise in real gold prices.

Four explanations for the unsatisfactory operation and early collapse of the fixed exchange rate system can be distinguished. Nurkse (1944) emphasized the failure of central banks to play by the "rules of the game" -- in other words, their tendency to disregard balance-of-payments targets and to adapt policy instead to domestic economic conditions. Kindleberger (1973) emphasized the failure of the leading participant, the United States, to accept its responsibility for stabilizing the system by acting as international lender of last resort. Clarke (1967) and Eichengreen (1985) emphasized the lack of international economic policy coordination among the U.S., Britain, France and Germany. Finally, Mlynarski (1929) emphasized intrinsic instabilities -- structural flaws -- in the reconstructed system.

The gold exchange standard did not even guarantee nominal exchange rate stability. The fixed rate system began to crumble in 1929, after barely three years of operation. Argentina and Uruguay suspended gold payments in December of that year. Canada 
introduced new monetary restrictions tantamount to devaluation. Brazil, Chile, Paraguay, Peru, Venezuela, Australia and New Zealand, without officially suspending gold convertibility, permitted their currencies to slip below par.

In 1931 depreciation spread to the industrial center. Austria and Germany, having experienced a decline in long-term capital inflows from the U.S. and the U.K. and confronting domestic banking panics, suspended gold convertibility and imposed exchange controls. Much of Eastern Europe followed. In general, these countries maintained their official gold parities but were able to adopt more expansionary policies, given the insulation of exchange controls. Britain's balance of payments weakened for different reasons, namely a decline in interest and dividends on investments overseas. The devaluation of sterling in 1931, following a run on the Bank of England's reserves, induced some two dozen other countries to follow suit. Many pegged their currencies to the pound and, as time passed, held an increasing proportion of their international reserves in the form of sterling deposits in London. The world of international finance thus was partitioned into three segments: one in which currencies were pegged to gold, a second in which they were pegged, sometimes loosely, to sterling, and a thind in which exchange control dominated. A few countries belonged to neither group: Canada, for example, split the difference between sterling and the dollar, while Japan depreciated markedly relative to sterling.

The next round of devaluations occurred in 1933, when Roosevelt took the U.S. off gold. The dollar lost 41 per cent of its value against the gold standard currencies in the following nine months. Cuba, Guatemala, Panama and the Philippines quickly followed the U.S. off gold. Many of the South American countries allowed their currencies to depreciate further to maintain their competitiveness in the U.S. market, creating an informal dollar area. This pseudo dollar area lacked the stability and definition of its sterling counterpart, however. With France, Belgium, Switzerland, the Netherlands, Czechoslovakia and Poland still maintaining gold convertibility and the Sterling Area countries tightening their pegs, the world was now fragmented into not two but three currency areas. The pressure on the remaining gold standard countries intensified as their number dwindled. Czechoslovakia devalued in 1934. Belgium was forced to devalue in 1935, France in 1936. France's action having reduced the group of gold standard countries enjoying exchange rate stability vis a vis one another to a negligible residual, those which remained devalued in response.4/ 
A notable aspect of this episode is the extent to which govemments attempted to influence currency movements through foreign exchange market intervention. In contrast to the experience with freely floating rates in the first half of the 'twenties, between 1932 and 1936 governments intervened continuously to damp fluctuations. Exchange equalization funds were established for the purpose. Endowed typically with some of the capital gains accruing to the authorities with the revaluation of the national gold reserve, these funds were charged with damping temporary exchange rate fluctuations. Whether to sterilize their intervention was officially a matter for the central bank, not for the Treasury authorities who controlled the equalization fund. It is suggested, however, that these funds sometimes operated in concert with the central bank to artificially depress the exchange rate, with the goal of enhancing the intemational competitiveness of domestic producers.5/

Accounts of this managed floating regime portray it as no more satisfactory than the eras of free floating and fixed rates that preceded it. The transition to managed floating is portrayed as especially damaging. Devaluations were beggar thy neighbor. They exacerbated the Great Depression overseas, it is alleged, while doing nothing to promote economic recovery in the initiating country.6/ Following the transition to managed floating, other damaging consequences surfaced. Although the authorities may have succeeded in reducing exchange rate volatility, they failed to eliminate exchange rate unpredictability. The uncertainties that ensued discouraged investment and exports that could have hastened recovery from the Great Depression.

Thus, the literature conveys an overwhelmingly negative impression of all three exchange rate regimes. Beyond this negative assessment, it provides little information with which to gauge the comparative performance of the alternative systems. It is to this question that I now turn.

\section{Implications for Asset and Commodity Markets}

The exchange rate data analyzed in this section are drawn mainly from Einzig (1937). Einzig compiled forward market quotations from weekly circulars of the Anglo-Portuguese Colonial and Overseas Bank. The spot and forward market observations are for the close of business each week. The forward rates are for delivery in 90 days. 

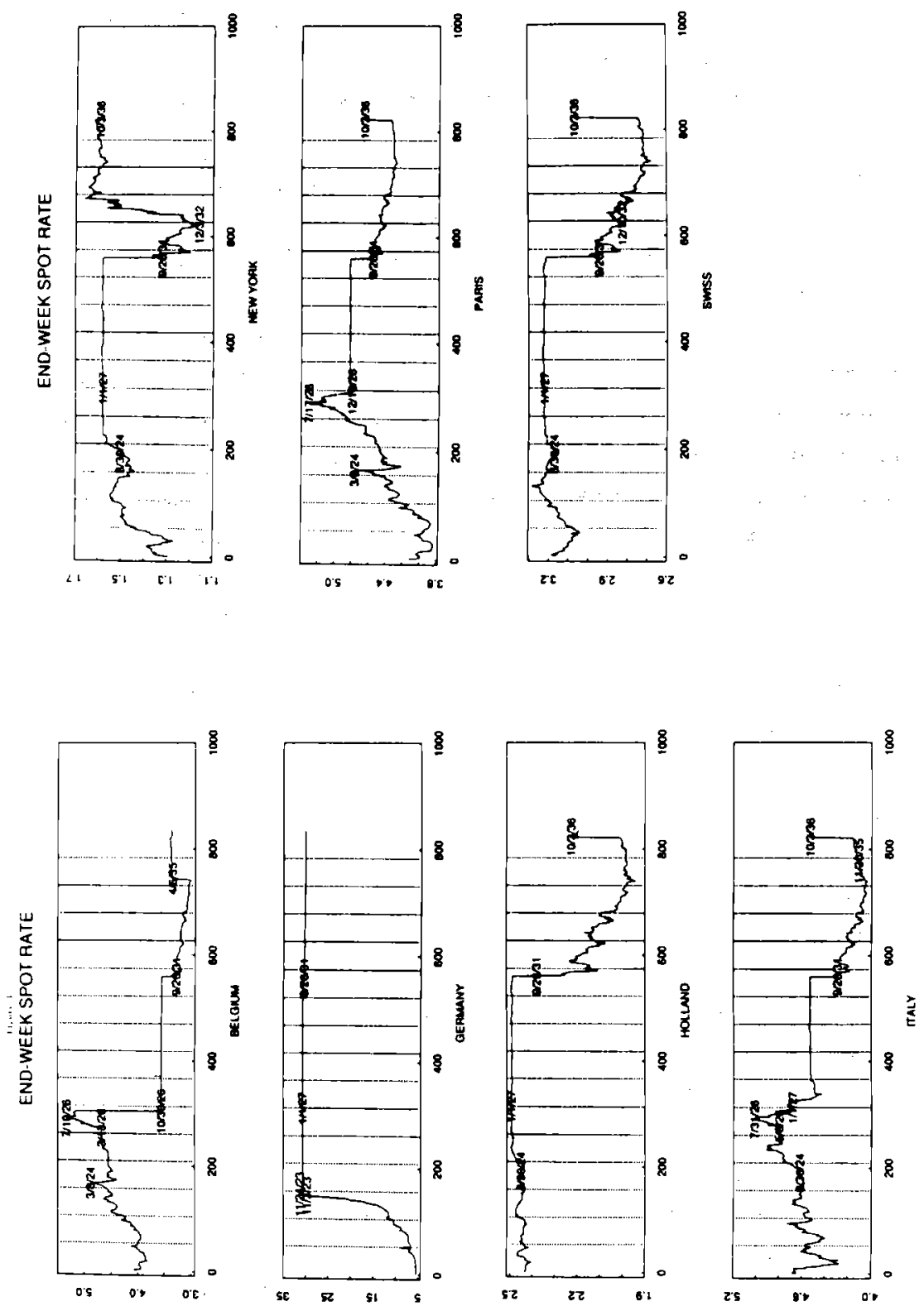
Einzig's data cover seven countries: the U.S., Britain, Switzerland, France, the Netherlands, Belgium, Italy and Germany. These are the countries to which the analysis will be limited when forward market data are employed. When spot rates only are utilized, the sample can be extended to other countries, using exchange rate quotations drawn from The Economist Magazine and the Monthly Statistical Bulletin of the League of Nations. When nominal and real exchange rates are compared, both are computed as monthly averages using data on nominal exchange rates and wholesale prices from the League of Nations.

The three periods I consider are January 1922 through August 1926 (free floating), January 1927 through August 1931 (fixed exchange rates) and January 1932 through August 1936 (managed floating). As always, the division into periods is arbitrary. Continuous quotations of forward rates first become available in January 1921, but for reasons having to do with the availability of other variables, it is convenient to start the analysis in January 1922.7 I choose January 1927 to mark the start of the fixed exchange rate period, since the French franc was stabilized in December 1926. Since most of the other currencies considered were stabilized at somewhat earlier dates, the choice of January 1927 should highlight the distinguishing features of the fixed rate period. I end the fixed rate period with August 1931. Britain floated the pound in September 1931, with Sweden, Norway and Denmark following at the end of September, Finland in October, and Japan in December. But policies designed to manage the fluctuation of these exchange rates were only adopted in 1932. For this reason (and for symmetry with January 1921 and January 1927), I choose January 1932 to mark the start of the period of managed floating. I end the analysis in August 1936, the month before France, the Netherlands and Switzerland devalued and the international monetary system was again transformed. The two periods of transition between regimes (September December 1926 and September - December 1931) are difficult to assign to a particular period. I therefore omit them entirely.

I follow Einzig by using the pound sterling as the reference currency. The choice of reference currency for the computation of bilateral rates makes little difference for most of the conclusions that follow. 8 It turns out to matter for rankings of exchange rate stability across countries within periods, but not for rankings of overall stability across periods. Obviously, countries which pegged to sterling appear to have enjoyed the greatest exchange rate stability when sterling is used as the reference currency, while 

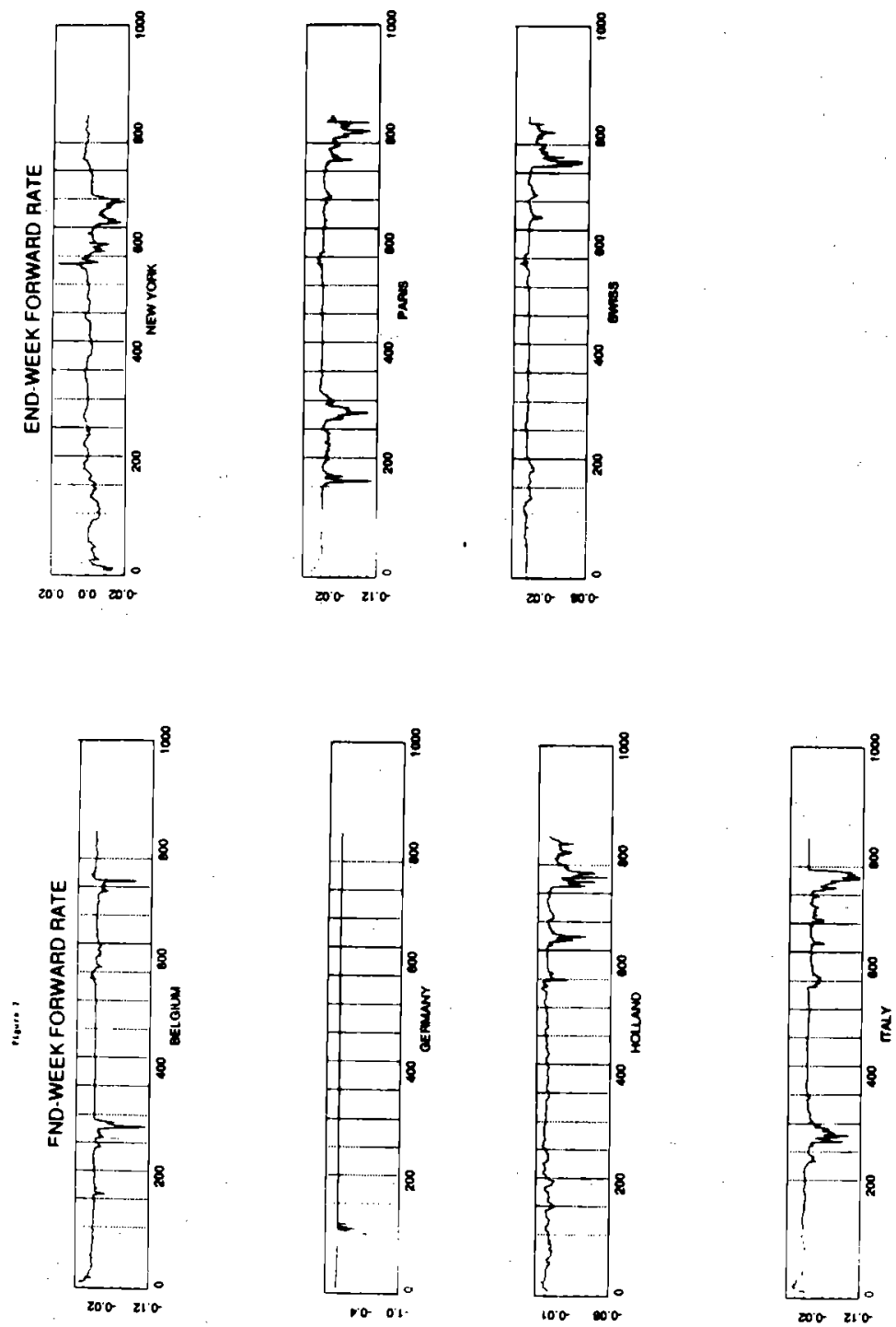
countries which pegged to other currencies appear to have enjoyed the greatest stability when those other currencies are used. But the average volatility of exchange rates under free floating compared to managed floating is largely unaffected by the choice of bilateral rate.

Here even more than in other similar analyses, conclusions are likely to be dictated by outliers. The extreme behavior of exchange rates, interest rates and prices during the German hyperinflation has a profound influence on international averages for 1921-26 compared to 1927-31 or 1932-36 even when a relatively large cross section of countries is considered. Therefore, I recalculate many of the summary statistics omitting the German data.

Figures 1 and 2 show the weekly spot and forward rate data for the entire period. Visual inspection of Figure 1 makes clear that spot rates behaved very differently between 1927 and 1931 than either before or after but does not suggest clear hypotheses about the relative stability of spot rates under free and managed floating.9/ The French, Belgian and Italian rates appear to have been more volatile in the early 'twenties than in the early 'thirties, but it is not clear that this generalization holds for Holland, Switzerland or the United States. Similarly, French, Belgian and Italian forward discounts appear to the naked eye to have displayed more volatility under free floating in the 'twenties than under managed floating in the 'thirties, but the same is not clearly true of Holland, Switzerland and the United States.

Table 1 summarizes the variability of spot exchange rates under the three regimes. The exchange rate is defined as the foreign-currency price of the home currency. I measure variability by the standard deviation of the first difference in the log spot rate. By that measure, nominal exchange rate variability was greater during the period of freely floating exchange rates at the beginning of the 'twenties than under managed floating in the 'thirties. It was very considerably greater, of course, under both periods of floating than under pegged rates from 1927 through 1931. Part of the contrast between 1922-26 and 1932-36 derives from the extreme behavior of exchange rates during the German hyperinflation. But even with the Germany omitted, the standard deviations for 1922-26 are on average 40 per cent larger than those for 1932-36. Intervention seems to have been associated with increased nominal exchange rate stability. 
Table 1

Standard Deviations of Spot Rates and Risk Premia: Weekly Data

( $\mathfrak{f}$ as reference currency)

$\begin{array}{lll}\frac{\text { Period 1 }}{1922-26} & \frac{\text { Period 2 }}{1927-31} & \frac{\text { Period 3 }}{1932-36}\end{array}$

Spot Rates: $\log S_{t}-\log S_{t, 1}$

$\begin{array}{llll}\text { Belgium } & .03307 & .00052 & .01715 \\ \text { Germany } & .34851 & .000956 & .01053 \\ \text { Netherlands } & .00331 & .000743 & .00959 \\ \text { Italy } & .01917 & .008140 & .00984 \\ \text { U.S. } & .00532 & .000637 & .01426 \\ \text { France } & .03572 & .000794 & .00912 \\ \text { Switzerland } & .00567 & .000844 & .01117 \\ \text { mean w/o Germany } & .01704 & .000195 & .01221 \\ \text { mean w/Germany } & .06440 & .001802 & .01199\end{array}$

Risk Premia: $\log F_{t}-\log S_{1+1}$

\begin{tabular}{|c|c|c|c|}
\hline Belgium & .12582 & .00173 & .07588 \\
\hline Germany ${ }^{d}$ & .59342 & .00288 & $N / A$ \\
\hline Netherlands & .01343 & .00218 & .03492 \\
\hline Italy" & .07558 & .04820 & .03722 \\
\hline U.S. & .02347 & .00246 & .05832 \\
\hline France & .11250 & .00278 & .03553 \\
\hline Swizerland & .02194 & .00325 & .03589 \\
\hline mean w/o Germany & .06212 & .01010 & .04913 \\
\hline mean w/Germany & .20817 & .00907 & N/A \\
\hline
\end{tabular}

Notes: * Missing 11/30/35 - 12/21/35 (5 obs)

- Missing 3/1 1/33 (2 obs)

- Missing 12/10/32 (2 obs)

d Missing 1923.09- 1924.11

- Missing 11/30/35 - 8/31/36

Source: See text. 
The ex post risk premium (the log forward rate minus the log spot rate at the time the forward contract matures) is shown in Figure 3. The bottom panel of Table 1 shows that on average the magnitude of the risk premium declined along with the variability of the spot rate with the shift from free to managed floating. But the extent of the decline is relatively small. The variability of the spot rate falls by 28 per cent between the early 'twenties and early 'thirties (Germany omitted), whereas the average risk premium falls only by 21 per cent.10/

The extreme variability of the risk premium is episodic. These episodes of large risk premia tend to be associated with strong (overvalued?) exchange rates and coincide with depreciation abroad. Large risk premia in the 1930s are evident in the panels of Figure 3 for France, Holland and Switzerland. The panel for Holland, for example, displays large spikes in the autumn of 1931 (following the devaluation of sterling), the summer of 1933 (following devaluation of the dollar) and the summer of 1935 (following devaluation of the belga).

The overall picture is one in which the reduction in nominal exchange rate variability achieved with the shift from free to managed floating was not accompanied by a comparable reduction in the exchange risk premium. An interpretation is that government policy succeeded in damping fluctuations in spot exchange rates on average but was subject to periodic changes that were difficult to predict. That the decline in the variability of spot rates between the early 'twenties and early 'thirties was not accompanied, for most countries, by a commensurate decline in the variability of the risk premium suggests that the greater stability of spot rates in the 'thirties did not imply a comparable reduction in uncertainty, nor did it necessarily signify a significant improvement in welfare.

Table 2 summarizes the variability of the real exchange rate under the three regimes. Since wholesale price level data are not available for a wide sample of countries on a weekly basis, the real exchange rates in Table 2 are computed as monthly averages. The standard deviation of the first difference of the log real rate is on average 15 per cent larger in the period of free floating than under managed floating.11/ The correlation between the standard deviation of the first differences of (log) nominal and real rates is extremely high in both the early 'twenties and the early 'thirties. For both periods, a regression of the standard deviation of real rates on the standard deviation of average 


\section{Table 2}

Standard Deviations of Real Exchange Rates: Monthly Rates (mid-points) ( $£$ as reference currency)

Real Exchange Rate: $\log R_{1}-\log R_{r-1}$

$\frac{\text { Period 1 }}{1922-26} \quad \frac{\text { Period 2 }}{1927-31} \quad \frac{\text { Period 3 }}{1932-36}$

$\begin{array}{llll}\text { Belgium } & .0480 & .0105 & .0330 \\ \text { Germany" } & .1380 & .0077 & .0212 \\ \text { Netherlands } & .0148 & .0109 & .0231 \\ \text { Italy } & .0371 & .0156 & .0204 \\ \text { U.S. } & .0153 & .0102 & .0358 \\ \text { France } & .0395 & .0129 & .0194 \\ \text { Switzerland } & .0173 & .0113 & .0205 \\ \text { mean w/o Germany } & .0292 & .0121 & .0254 \\ \text { mean w/Germany } & .0584 & .0114 & .0248\end{array}$

Notes: - Missing 1923.09 - 1923.12 due to break in wholesale price index.

Source: Sce text. 

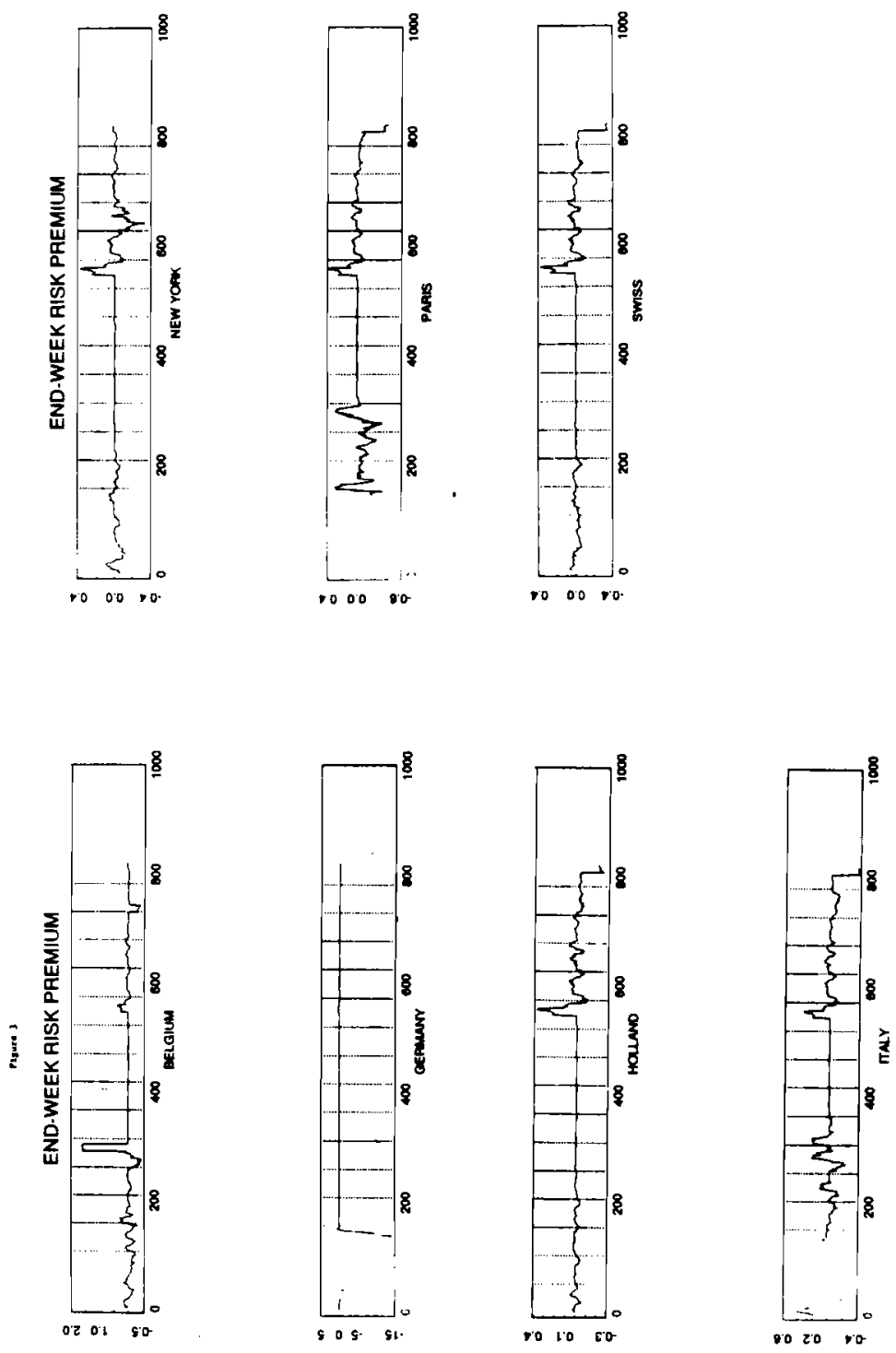
monthly nominal rates (and on a constant term) yields t-statistics indicating statistical significance at better than the 99 per cent level.12/

These questions can be considered from another perspective, subject to assumptions about the information used to predict exchange rates. Table 3 summarizes the variability of the residuals from a standard exchange rate forecast. The log spot rate is regressed on a constant term and its own lagged value, and the standard deviation of the residuals from the forecasting equation is computed.13/ Monthly data are used (to facilitate comparisons with real exchange rates) and, since forward rate data are not utilized, the sample of countries can be expanded. Although the standard deviations of the exchange rate forecasts are larger under the managed float of the 'thirties than the free float of the 'twenties for five of the 11 countries, on average (excluding Germany) this measure of exchange rate unpredictability falls by about 15 percent when moving from the free to the managed float. Consistent with Table 1 , this suggests that the reduction in exchange rate risk was smaller than the accompanying reduction in exchange rate variability.

Also interesting is the analogous measure of real exchange rate predictability in the second panel of Table 3. The standard deviation of the residuals from the real exchange rate forecast is larger under managed floating in 7 out of 10 cases (Germany excluded). The unweighted average of this measure of the forecast error is nearly 10 per cent larger under managed floating in the 'thirties than under free floating in the 'twenties (Germany again excluded). The exceptions are the high inflation countries of the 'twenties: France, Belgium and Italy. It would appear that there is a positive association between nominal and real exchange rate unpredictability when nominal rate variability and unpredictability reach high levels; otherwise other factors may dominate the unpredictability of real rates. There is some evidence of a positive relationship between the predictability of nominal exchange rates and the predictability of real exchange rates in both periods of floating.14/ That relationship is slightly stronger under free than managed floating: the correlation coefficient for the real and nominal exchange rate forecast errors is 0.89 under free floating (10 countries, excluding Germany) and 0.74 under managed floating (11 countries).15/

The behavior of these variables is strikingly different during the period of fixed exchange rates. The standard deviation of the log difference in the spot rate was an order of magnitude smaller, by definition (Table 1). The standard deviation of the risk premium was also smaller, by approximately the same proportion. Table 3 confirms that 
Table 3

Exchange Rate Predictability

(Standard deviations of residuals from exchange rate forecasts)

$\begin{array}{lll}\frac{\text { Period 1 }}{1922-26} & \frac{\text { Period 2 }}{1927-31} & \frac{\text { Period 3 }}{1932-36}\end{array}$

Nominal Exchange Rate Predictability (in logs)

\begin{tabular}{|c|c|c|c|}
\hline Denmark & .03264 & .0051 & .03070 \\
\hline Finland & .02621 & .00168 & .02985 \\
\hline Norway & .03252 & .00311 & .02808 \\
\hline Sweden & .01061 & .00178 & .02995 \\
\hline Switzeriand & .009937 & .001568 & .01729 \\
\hline U.S. & .010504 & .00168 & .02781 \\
\hline France & .06329 & .00088 & .01689 \\
\hline Netherlands & .00626 & .001199 & .01694 \\
\hline Belginm & .06998 & .00093 & .04190 \\
\hline Italy" & .03654 & .01361 & .01953 \\
\hline Germany" & .3580 & .001286 & .01953 \\
\hline Germany ${ }^{b}$ & .014597 & & \\
\hline \multirow{2}{*}{$\begin{array}{l}\text { Average excluding } \\
\text { Germany }\end{array}$} & .029849 & .002795 & .025894 \\
\hline & \multicolumn{3}{|c|}{ Real Exchange Rate Predictability (in logs) } \\
\hline Denmark & .02090 & .02055 & .02956 \\
\hline Finland & .01819 & .01193 & .0309 \\
\hline Norway & .02938 & .01226 & .0323 \\
\hline Sweden & .01384 & .00930 & .0303 \\
\hline Switzerland & .01553 & .01084 & .01863 \\
\hline U.S. & .01333 & .01019 & .02633 \\
\hline France & .03661 & .01323 & .01614 \\
\hline Netherlands & .01456 & .01078 & .02203 \\
\hline Belgium & .03589 & .01007 & .02685 \\
\hline Itally" & .03655 & .01361 & .01953 \\
\hline Germany & .10836 & .00755 & .01953 \\
\hline Germany & .01760 & & \\
\hline $\begin{array}{l}\text { Average excluding } \\
\text { Germany }\end{array}$ & .02348 & .01128 & .02526 \\
\hline
\end{tabular}

Notes: - $1922.01-1923.07$ and $1923.12-1926.08$

- $1922.01-1922.05$ and $1924.01-1926.08$

- $1922.01-1923.07$ and $1924.01-1926.08$

- $1924.02 \cdot 1926.08$

- 1935.12 - 1936.02 omitted due to missing data.

Source: See text. 
the greater stability of spot rates in the gold-exchange standard period enhanced the predictability of the spot rate. It also enhanced the predictability of the real rate. For all but two countries, the real rate was easier to predict in the fixed rate period than in either period of floating rates. This is impressive given the momentous terms of trade shocks to which the world economy was subjected between 1929 and 1931.16 /

Evidence that the nominal exchange rate regime had implications for the variability and predictability of real exchange rates suggests that it also may have affected other real variables responsive to relative price movements. Table 4 shows the standard deviation of the first difference of annual detrended ( $\log$ ) differences in industrial production for all three periods.17 (A separate linear trend is fitted for each subperiod.) The variability of fluctuations of industrial production around trend was greatest on average in the period of freely floating exchange rates (1922-26). Variations around trend were about twice as pronounced in the period of free floating as in the period of managed floating (1932-36). But there exists no simple correlation between the nominal exchange rate regime and the variability of output fluctuations. In the period of fixed rates (1927-31), fluctuations of output around trend were more variable than in the subsequent period of managed floating rates. Obviously, factors in addition to the nominal exchange rate regime conditioned the severity of the cycle. The naive explanation is that the fixed rate period coincides with the onset of the Great Depression. In fact, the Depression is split between the fixed and managed-floating periods. In many countries, the upswing was initiated every bit as rapidly after 1931 as the downturn set in after 1928. The important difference between the three periods lies in the fact that 1922-26 and 1932-26 comprise expansion phases of the business cycle in most of the countries in the sample, while 1927-31 spans the end of an expansion phase and the beginning of contraction; thus a linear trend explains less of the variance in the middle period.

A more revealing characterization of the cyclical implications of different exchange rate regimes appears in Table 5. It reports the correlation between detrended changes in industrial output in each European country and detrended output changes in the United States.18/ Data definitions and detrending methods are the same as in Table 4 above. The hypothesis underlying this table is that countries were more susceptible to external disturbances under fixed exchange rates. Industrial production in the U.S., the largest industrial power of the period, is taken as a proxy for the extemal disturbances to which the European economies were subjected. The contrasts among periods are striking. The 
Table 4

Standard Deviations of Detrended Log Differences

of Industrial Production

Period 1

1922-26

Belgium
Denmark
Finland
France
Germany
Italy
Netherlands
Swizerland
Norway
Sweden
U.S.
U.K.
12 country average
Average exciuding
Germany

Period 2

1927-31

.07632

.08149

.06258

.10970

.06892

.10395

.12811

.09266

.14494

.06277

.06277

.03554

.08575

.08728
Period 3

1932-36

.03040

.07651

.03180

.09920

.11120

.10940

.07451

.03249

.01542

.07056

.07314

.04229

.05641

.06143

Source: See text. 
average correlation of industrial production fluctuations in Europe with industrial production movements in the United States is three times as large under managed floating as under freely floating exchange rates, and twice as large again under fixed rates as under managed floating. It appears that vulnerability to external disturbances was an increasing function of the stability of nominal exchange rates under the prevailing international monetary regime.

A possibility suggested by the grouping of countries in Table 5 is that the synchronization of business cycle disturbances may have varied across currency blocs in the 1930s. Not only might have industrial production in countries which pegged to the dollar have moved closely with industrial production in the U.S., but industrial production in sterling area countries would have moved closed with production in Britain if a sterling peg was an important determinant of the direction of international business cycle disturbances, and similarly for the members of the gold bloc. To test this hypothesis, I expanded the sample of countries to all those for which reasonable time series on industrial production could be obtained and which were readily categorized as members of an international monetary bloc in the 1930s. I distinguish gold bloc countries, members of the sterling area, and the group of countries which, following Germany, adopted stringent exchange controls. The question is whether industrial production is more variable across currency blocs than within them.

To answer this question, I compute the relevant variance ratio. I first calculate the average variance within groups:

$$
\operatorname{Var}_{\text {within }}=(1 / n) \sum_{i=1}^{n}\left[1 /\left(N_{i}-1\right)\right] \sum_{j=1}^{N_{i}}\left(X_{i j}-\bar{X}_{1}\right)^{2}
$$

where $i$ indexes the group or currency bloc (of which there are $n$ ) and $j$ the member of that group. $X$ and $\bar{X}$ are the individual observation and the corresponding group mean. This is contrasted with the variance for the entire sample of $\mathrm{N}$ countries:

$$
\mathrm{Var}_{\text {tot }}=[1 /(\mathrm{N}-1)] \underset{\mathrm{i}}{\sum} \sum_{\mathrm{j}}\left(\mathrm{X}_{\mathrm{ij}}-\overrightarrow{\mathrm{X}}\right)^{2}
$$

where $N=\sum_{i=1}^{n} N_{i}$ 


\section{Table 5}

Correlation between Detrended 1 st Difference of

Log Industrial Production For 11 Countries and

Detrended 1st Difference of Log Industrial Production for the United States

$$
\frac{\text { Period } 1}{1922 / 23-25 / 26}
$$

Period 2

$1927 / 28-30 / 31$
Period 3

$1932 / 33-35 / 36$

$\begin{array}{lccc}\text { Belgium } & .11930 & -.48938 & .32412 \\ \text { Denmark } & .02477 & .54291 & .93253 \\ \text { Finland } & .86299 & .58823 & .66942 \\ \text { France } & -.29325 & .76677 & .03120 \\ \text { Germany } & -.77650 & .96724 & .59853 \\ \text { Italy } & .31334 & .92535 & .75760 \\ \text { Netherlands } & . .06323 & .73139 & .33509 \\ \text { Switzerland } & .42824 & .92194 & . .66008 \\ \text { Norway } & .45774 & .70943 & . .19172 \\ \text { Sweden } & -.09080 & . .01861 & .17119 \\ \text { U.K. } & .01989 & .97713 & .40347 \\ \text { Average } & .09114 & .60204 & .30659\end{array}$

Source: See text. 
If differences in output behavior are small within groups but large between groups, then the ratio of $\mathrm{Var}$ within to $\mathrm{Var}_{\text {tot }}$ should be significantly less than one.

The first column of Table 6 reports the components of the variance ratio. It shows that output variation within groups accounts for more than half of the total variation for the sample of 19 countries. (I calculate these statistics using one observation for each of the 19 countries: the average annual rate of growth of industrial production over the period.) One way to judge these ratios is to compare them with variance ratios for the same sample of countries for the immediately preceding fixed exchange rate period. The botrom panel of the table shows that the variance between groups explains almost none of the total variance in the gold standard period. It is striking is how much less of the total variance is accounted for by variation within groups in the subsequent period 1932-36. These patterns can be assessed formally by computing the F-statistic testing that there are no bloc-specific growth effects. The $F(2,16)$ of 6.2 for the 1930 s is borderline significant at the 99 per cent confidence level. That for 1927-31 is insignificant.

Insofar as output fluctuations were linked internationally by the adoption of a common peg, the plausible explanati 7 is that adherance a currency area required convergence of monetary and fiscal policies within currency blocs, while the maintenance of floating rates between sterling, the franc and the dollar, along with the adoption of exchange control elsewhere, permitted the divergence of policies across blocs. Table 6 therefore reports variance ratios for annual percentage changes in the money supply and the government budget deficit. Data for money supplies are taken from the same sources as above; those for the budget balance (adjusted to remove government borrowing from total revenues) are from various issues of the League of Nations' Public Finances. Table 6 confirms that adherence to a currency bloc induced monetary and fiscal policy convergence of its members. The variance between blocs accounts for the majority of the total variance of changes in money supplies in the sample. The F-statistic for money for 1932-36 is highly significant, but that for $1927-31$ is totally insignificant. The evidence on fiscal policy is more difficult to interpret. While the F-statistic testing for bloc-specific fiscal policy effects is highly significant for 1932-36 (indicating convergence), so is that for 1927-31. A possible interpretation is that the pressures which led some countries to go off gold in 1931 were already evident in their fiscal stances in the immediately preceding years.

In summary, the nominal exchange rate regime in effect for different portions of the interwar period had a first order impact on both asset and commodity markets. Nominal 
Table 6

Variance Ratio Decompositions

(variance * 1,000 )

$\underline{1932 / 33-1935 / 36}$

Industrial
Production

Variance Within

Variance Between

Total Variance

1.9292

0.7976

0.4721

0.7873
19.936

Budget

Balance

6.256

13. 107

$1927 / 28-1930 / 31$

Variance Within

1.0547

0.8547

3.394

Variance Between

0.1272

0.0823

14.577

Total Variance

1.1819

0.9370

17.904

Notes: Countries are Belgium, France, the Netherlands and Switzerland (members of the gold bloc); Austria, Bulgaria, Czechoslovakia. Germany, Hungary, Italy, Poland and Yugoslavia (exchange control); and Australia, Denmark, Finland, New Zealand, Norway, Sweden and the U.K. (sterling area). Belgium is not included in money supply column. Australia, Italy and Bulgaria are not included in the industrial production column. Budget figures for Belgium, Netherlands, Austria, Hungary, Poland, Bulgaria, Germany, Italy, Yugoslavia, Australia, Denmark and New Zealand are for 1928/29 - 1930/31 rather than 1927/28 $1930 / 31$.

Source: See text. 
exchange rate variability was considerably greater under free than under managed floating. But the reduction of nominal variability under managed floating did not deliver a comparable reduction in nominal exchange rate uncertainty, whether measured by the exchange risk premium or the accuracy of a naive exchange rate forecast. Neither did it uniformly enhance the predictability of real exchange rates. The move to fixed nominal rates, in contrast, significantly enhanced the predictability of real exchange rates. The nominal exchange rate regime also had implications for the synchronization of business cycle disturbances across countries. The degree of synchronization was greater under fixed than under floating rates, and greater within currency blocs in the 1930s than across them. Differences in the degree of synchronization in turn reflect differences in the degree of convergence of policies.

\section{Causes of International Monetary Disintegration}

It had long been recognized that the sustainability of a fixed exchange rate depended on a willingness to adopt policies consistent with the exchange rate target. Since the essence of a fixed exchange rate under the gold-exchange standard was the maintenance of a stable domestic currency price of gold, the supply of domestic currency had to be adapted to variations in the demand that obtained at the price fixed by statute. The price-specie flow mechanism brought about this result automatically under a gold coin standard. It continued to do so under a gold bullion standard so long as the authorities maintained the convertibility of domestic currency into gold and did not otherwise alter the money supply. Moreover, central banks could minimize the need for gold movements by altering domestic monetary conditions in the direction dictated by incipient gold flows. They could respond to a gold outflow with an open market sale, reducing the monetary base, or raise the discount rate, reducing the money multiplier. Either initiative would bring about the requisite stringency in domestic financial markets and minimize the need for further gold flows. This, following Keynes (1925), came to be known as playing by the rules of the game.

The first explanation for the inadequacies of the adjustment mechanism under the interwar gold standard and for that system's early demise was the failure of central banks to play by the rules of the game. Rather than reinforcing the impact on domestic money and credit conditions of incipient intemational gold flows, policymakers sterilized reserve movements instead. Nurkse (1944) tabulated the number of instances, in annual data, 
when the domestic and foreign assets of central banks moved in the same direction, as they would have if changes in foreign reserves were permitted to alter domestic money supplies, and the number of instances in which they moved in opposite directions, as they would have when central banks engaged in sterilization. He found that only a minority of central banks obeyed the rules of the game, 32 per cent in 1927, 21 per cent in 1928, 20 per cent in 1929, 35 per cent in 1930 and 19 per cent in 1931.19/

Arthur Bloomfield (1959) criticized Nurkse's conclusion on the grounds that, by Nurkse's own measure, central banks violated the rules of the game every bit as often between 1880 and 1913. Therefore, he argued, violations of the rules could not explain the in stability of the interwar gold standard since they had been equally prevalent under its admirably stable prewar ancestor. But Bloomfield based his comparison on the entire interwar period and the years 1880-1914. When the comparison is limited to the two periods of fixed rates (1880-1913 and 1927-31), it is clear that violations of the rules were not equally prevalent before 1913. A rise in the incidence of those violations can help to account for the instability of the interwar system.

Other historical developments lend plausibility to this argument. In many countries, the extent of the franchise was broadened as a result of World War I. It no longer was conscionable -- or in any case feasible -- to send members of the working class off to war without also entitling them to vote. The consequent growth of parliamentary labor parties created pressure to direct monetary policy toward the ieduction of unemployment rather than to abstruse financial ends. The rise in recorded unemployment rates lent the matter additional urgency. Even before the Great Depression struck, industrial unemployment rates in many countries had reached unprecedented levels. For the first time, reputable experts such as Keynes advanced arguments of how monetary conditions could be systematically manipulated to improve the state of the domestic economy.

A standard approach to testing for violations of the rules of the game is to estimate reaction functions relating the change in domestic assets both to the change in foreign assets and to the change in other variables likely to influence the stance of monetary policy. Time series regressions are used to confirm or reject that particular central banks obeyed the rules.20/ Here I adopt a slightly different approach, analyzing the behavior of a cross section of 21 countries. Table 7 reports regressions relating the (percentage) change in domestic assets to the change in foreign assets and to the change in industrial production (a proxy for the state of the domestic economy).21/ The uniformly negative 

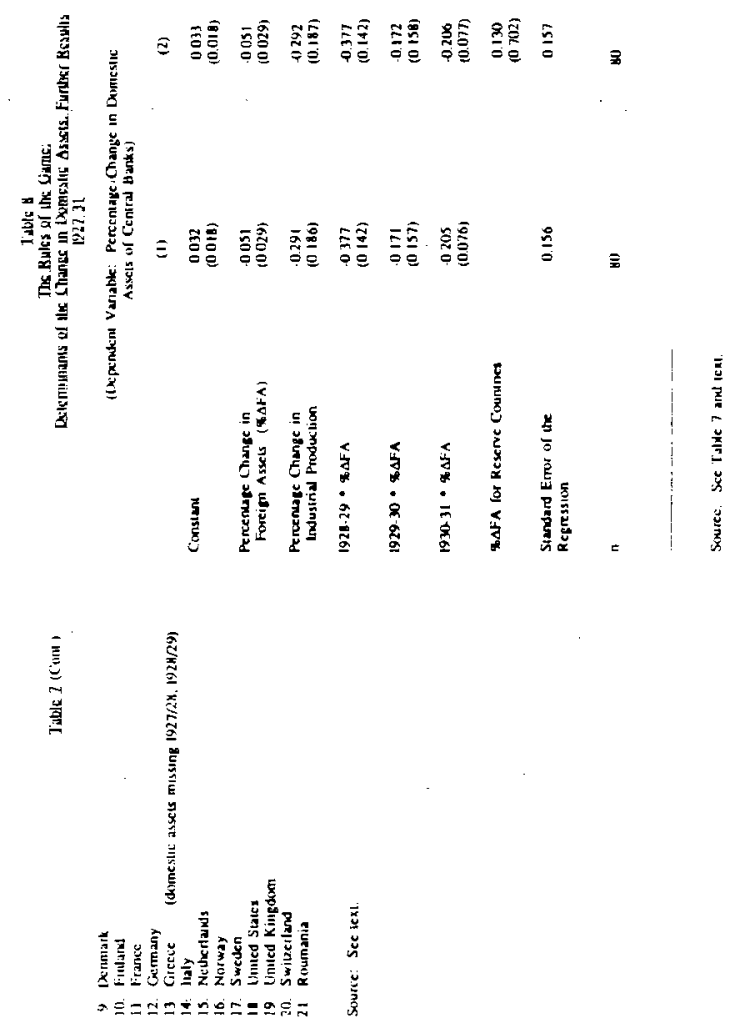

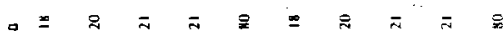

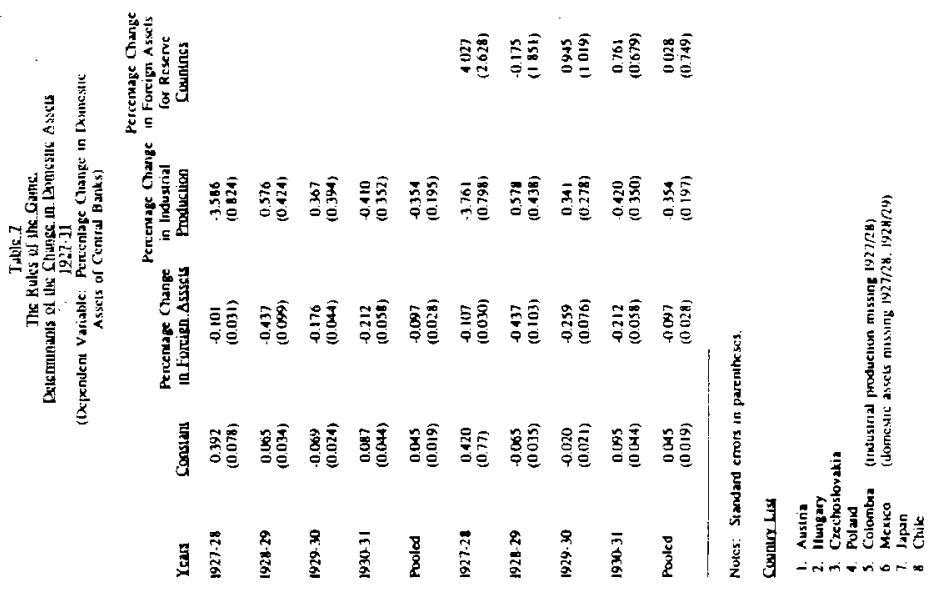


coefficients on the change in foreign assets confirm that central banks tended to sterilize reserve flows in each year of the system's operation, in violation of the rules. In contrast, the coefficients on the change in industrial production are unstable. In 1927-28 there seems to have been an attempt to use monetary policy in countercyclical fashion. Subsequently, there is no clear relationship.

Can these findings help to explain the increasing difficulties of the interwar system as the fixed exchange rate period progressed? Table 8 shows that the coefficient on foreign assets tended to increase in absolute value after 1927-28. In effect, sterilization became more complete, consistent with the hypothesis that domestic monetary policies not directed toward extemal targets were a part of the problem. At the same time, it should be noted that the coefficient reaches its largest absolute value in 1928-29, not in 1930-31. Something else in addition to the growth of sterilization presumably contributed to the system's collapse in 1931.

A second explanation for the instability of the interwar system emphasizes inadequate leadership. Kindleberger (1973) argues that the stability of a system of fixed exchange rates requires management by a leading international financial power. This leading power, or hegemon, must serve as international lender of last resort, providing liquidity to weak links in the chain of fixed exchange rates. It must do so both by engaging in countercyclical, or at least stable, long-term lending and by providing emergency loans to foreign central banks in times of crisis. The hegemon can further ease balance-of-payments pressure on weak-currency countries by maintaining an open market for their exports. Absent such intervention, the weak links will be forced to devalue, permitting skepticism about the stability of other currencies to spread and threatening the viability of the system. Thus, by offering loans to the weak-currency countries, the hegemon supplies the international public good upon whose adequate provision the viability of a system of fixed exchange rates depends. This explanation differs from the preceding one in that the stability of the system of fixed rates depends not just on individual national policies but on the adequate provision of this international public good.

According to Kindleberger, Britain served as hegemon prior to 1913, as did the U.S. after 1945. The instability of the interwar gold exchange standard reflected the fact that Britain was no longer able to stabilize the system, whereas the United States was not yet willing to do so. Lending was procyclical rather than countercyclical. The provision of 
Table 8

The Rules of the Game:

Determinants of the Change in Domestic Assets, Further Results $1927-31$

(Dependent Variable: Percentage Change in Domestic Assets of Central Banks)

(1)

$\begin{array}{lcc}\text { Constant } & 0.032 & 0.033 \\ & (0.018) & (0.018) \\ \text { Percentage Change in } & -0.051 & -0.051 \\ \text { Foreign Assets }(\% \Delta \mathrm{FA}) & (0.029) & (0.029) \\ \text { Percentage Change in } & -0.291 & -0.292 \\ \text { Industrial Production } & (0.186) & (0.187) \\ 1928-29 * \% \Delta \mathrm{FA} & -0.377 & -0.377 \\ & (0.142) & (0.142) \\ 1929-30 * \% \Delta \mathrm{FA} & -0.171 & -0.172 \\ & (0.157) & (0.158) \\ 1930-31 * \% \Delta \mathrm{FA} & -0.205 & -0.206 \\ & (0.076) & (0.077) \\ \text { \% } & & 0.130 \\ & & (0.702) \\ \text { Standard Error of the } & & 0.157 \\ \text { Regression } & 0.156 & 80 \\ & & \end{array}$

Source: See Table 7 and text. 
emergency liquidity to foreign central banks was inadequate. Rather than maintaining an open market, the United States adopted the Smoot-Hawley Tariff at the worst possible moment.

While this explanation contains a kernel of truth, its importance can be exaggerated. The period to which it best applies is the early years of the Bretton Woods System, when U.S. dominance of international financial and commodity markets was unrivaled.21/ By the 1960s, the stability of the Bretton Woods System hinged not on hegemonic leadership by the United States but rather on collective management by the industrial countries, through gold pooling, policy coordination and the willingness to hold dollar reserves exclusively in order to stabilize the system. For the period prior to 1913 , it is even clearer that the stability of the system depended on collective, not hegemonic, management. Notwithstanding Britain's preeminence in international markets, fending off convertibility crises required assistance by a group of central banks. On several occasions the Bank of England was the international borrower of last resort, and Continental central banks like the Bank of France were the international lenders. Insofar as the international economic difficulties of the 1920s and 1930s illustrated the importance of collective management, this was neither the first nor the last time when the observation would be pertinent.

The recognition that international monetary stability could be critically affected by the actions of the entire group of industrial countries provides the rationale for the third explanation which emphasizes international cooperation. According to Clarke (1967), the collapse of the gold-exchange standard resulted from the failure of cooperation between the central banks of Britain, France, Germany and the United States. Cooperation was adequate through the summer of 1928, a dismal failure thereafter. The death of Benjamin Strong, who as Governor of the Federal Reserve Bank of New York played a leading role in the international economic affairs of the United States, dealt the fatal blow. Strong was on good personal terms with his British counterpart, Montagu Norman, and with other foreign central bankers. This enabled them to negotiate a cooperative solution to the sterling crisis of 1927.23/ Strong's successor, Benjamin Harrison, attached less weight to the affairs of other nations, and cooperation was not forthcoming in 1929 or 1931.

Clarke's thesis has been objected to on grounds of timing and for its emphasis on personalities.24/ One can cite significant instances of failed cooperation before 1928 and 
successes thereafter. It is difficult to believe that the fate of the international monetary system would have differed fundamentally had Benjamin Strong's health been more robust.

Even if one rejects Clarke's definition of cooperation, which focuses on negotiations among central bankers, as well as the sharp distinction he draws between the pre- and post-1928 years, it is still possible to argue that the failure of international cooperation contributed to the collapse of the fixed-rate system. The argument is that France and the United States, in particular, failed to coordinate their macroeconomic policies internationally. The two central banks possessed incompatibly large demands for the world's scarce gold reserves. They pursued tight monetary policies in an effort to obtain gold from one another. As in a noncooperative game, their efforts were offsetting and resulted in a suboptimal equilibrium. The cooperative solution would have been a coordinated reduction in discount rates which left the international distribution of gold unchanged but exerted expansionary pressure on their economies. As Keynes put the point, "What helps each central bank is not a high Bank rate but a higher rate than the others. So that a raising of rates all round helps no one until, after an interregnum during which the economic activity of the whole world has been retarded, prices and wages have been forced to a lower level."25/ In this view, it was the failure of international economic policy coondination, and the inability or unwillingness of any one central bank to expand unilaterally in the presence of the external constraint, that brought about the post-1928 deflation.

France and the United States were not the only countries involved. For both to remain in surplus throughout the period, someone else had to be in deficit. The someone else was industrial countries with weak currencies, such as Britain and Germany, and the primary-product exporters. Not only were the noncooperative strategies pursued by the central banks of the surplus countries a source of deflationary pressure on the world economy, but they heightened the vulnerability of other central banks to speculative attack. By draining reserves from the coffers of the Reichsbank and the Bank of England, they increased the susceptibility of these central banks to destabilizing shocks. Inadequate international policy coondination thereby helps to account for the instability of the intemational monetary system as well as for the collapse of prices and economic activity. 
This framework permits a reformulation of Kindleberger's emphasis on leadership. Leadership can be modeled as the Stackelberg strategy in a noncooperative policy game. The Stackelberg leader, say the United States, could lower its discount rate, despite the impact of such a policy on its reserve position, because it correctly anticipated that other countries would respond in kind. By intemalizing at least some of the international externalities associated with national economic policies, the leader-follower solution could be pareto superior to the Nash strategy described by Keynes.26/ But the gains from following exceed the gains from leading. The followers benefit from increased reserves and lower world interest rates. The leader, in contrast, benefits from lower interest rates but incurs a cost from lower reserves. While there are plausible conditions under which both leader and followers gain, each player prefers someone else to lead. Moreover, as the leader grows smaller relative to the international market, the gains from adopting the role of leader tend to diminish. Thus, this formulation both provides an explanation for the absence of leadership and helps one to understand why that problem was particularly serious in the increasingly multipolar international economy of the $1920 \mathrm{~s}$. At the same time, it suggests that if leadership had advantages over other forms of noncooperative behavior, full international economic cooperation had greater advantages still.

At precisely the same time policy coordination was becoming more difficult, it was becoming more important. With the growing weight attached to internal targets, the credibility of the commitment to the exchange rate was no longer above question. Speculative capital flows were less likely to flow in stabilizing directions. Policies which led to a drain of reserves of a given magnitude could have more serious ramifications for the stability of the international monetary system than before the war.

Each of the three explanations discussed so far focuses on misguided national policies. A fourth emphasizes instead flaws in the structure of the system. In this view, the intrinsic problem of the interwar system was that it was a gold exchange standard rather than a pure gold standard.27/ In principle, the dual nature of reserves under the gold exchange standard could create problems of stability by relaxing the external constraint on the reserve-currency countries. Those countries had no need to adjust to reserve losses, because they could finance them by providing domestic assets to foreign central bankers, who happily accumulated them as reserves. There would be no pressure to restore external balance. 
This thesis would predict excessive creation of international reserves and inflation, where the opposite was the case. It holds little water for the United States, which strained the international system by running persistent surpluses, not persistent deficits. It would predict an even weaker response by the reserve-currency countries, principally, Britain and the United States, to reserve inflows and outflows than was typical of other countries. Tables 7 and 8 test for this possibility by interacting the change in foreign assets with a dummy variable for the two reserve-currency countries. While the coefficient has the anticipated sign (suggesting that these countries took exceptionally feeble steps to alter domestic credit in response to changes in foreign assets), it is impossible to reject the hypothesis that these countries responded identically to the others in the sample.

A more plausible variant of the thesis emphasizes instabilities created by spontaneous portfolio shifts between alternative reserve assets. The problem is similar to the one highlighted by Triffin (1960) in his critique of the Bretton Woods System. Triffin emphasized the dynamic instability of a system which relied for international liquidity on gold and dollars. The flow supply of new gold being relatively inelastic, the incremental liquidity of the expanding international economy took the form predominantly of dollars. Once the stock of dollar claims held by foreign central banks approached the value of U.S. gold reserves, the U.S. commitment to peg the dollar price of gold would no longer be credible. The danger was that a run on the dollar would lead to a sudden contraction of the supply of international liquidity and to the collapse of the system.

The problem for the interwar system was similar. While the U.S. gold stock was sufficiently large relative to foreign claims that a forced devaluation of the dollar could be fended off, loss of confidence still ied to a massive liquidation of international reserves. The existence of two reserve currencies, sterling and the dollar, enhanced the ease with which central banks could shift between them. Once the suspension of convertibility by Austria and Germany in the summer of 1931 drove home the riskiness of exchange reserves, central banks and others began to shift out of sterling, the weakest reserve currency. Gresham's Law operated in reverse, with the good reserve driving out the bad. Britain's forced devaluation in September 1931 then shifted pressure toward the dollar. The Fed responded by tightening credit, which intensified pressure on foreign central banks already doing battle with weak payments positions and encouraged them to 
throw in the towel. In a counterfactual in which central banks held their reserves exclusively in gold, it would seem unlikely that the Austrian and German financial crises would have led to the liquidation of sterling on the same scale, or to the subsequent domino effects.

As noted above, the practice of holding foreign exchange reserves was not new. It had been encouraged and institutionalized precisely in the belief that the counterfactual of a pure gold-based system was not viable. The contemporary view was that the supply of gold had not increased over the first quarter of the 20th century at any anything approaching the increase in demand. To preclude a costly deflation, at the Genoa Conference in 1922 the British proposed formalizing the practice of holding reserves in convertible foreign exchange. While these proposals were not accepted, their spirit was incorporated into statutes adopted by central banks in subsequent years. The practice of holding foreign exchange reserves spread. This attempt to maintain diversified reserve portfolios of gold and foreign exchange created the possibility of a confidence-induced, spontaneous contraction in the reserve base, given the inability of any reserve country to unconditionally guarantee the convertibility of its currency into gold at a fixed price. And that spontaneous contraction of the supply of reserves could greatly intensify the pressure on central banks defending weak exchange rates. Thus, the hybrid nature of its reserve supply rendered the interwar system especially vulnerable to a destabilizing shock. $28 /$

This is where the Great Depression enters the story, since it was a destabilizing shock on a massive scale. The Depression led to a decline of nearly 50 per cent in dividends and interest earmings on British foreign investments, which accounted for more of the deterioration in the British current account than any other single item. It thereby rendered one of the two leading reserve currencies ripe for speculative attack. The curtailment of U.S, and British foreign lending that coincided with the onset of the Depression contributed to the payments difficulties of Austria and Germany. Together with the deterioration of industrial performance, this created difficulties for the two countries' banking systems. The Depression thereby paved the way for the Austrian and German banking panics and for their suspension of convertibility, which further undermined confidence in sterling. The terms-of-trade deterioration suffered by primary-product exporters moved their payments balances into deficit, eroded their reserves and increased their susceptibility to any further extemal shocks. Thus, when the 
liquidation of foreign exchange reserves and the scramble for gold induced a tightening of credit conditions, exchange rates were already poised on the verge of collapse.

The Depression plays an equally central role in the other explanations for the disintegration of the international monetary system. The deterioration in domestic economic conditions intensified the pressure felt by central banks to bend the rules of the game. A remarkable feature of the period is the extent to which central bankers continued to direct policy toward the defence of the exchange rate, despite the collapse of money supplies, prices and economic activity. But the deterioration in domestic economic conditions induced them to stretch the rules, in ways that heightened the danger of a convertibility crisis.

Similarly, the Depression magnified the international moretary consequences of the failure of cooperation. With the shock imparted to the system by the deepening Depression, the need for loans to provide emergency liquidity to weak central banks grew more pressing. The need for international coordination of macroeconomic policies to counter the macroeconomic crisis that was undermining their position became all the more urgent.

What lessons are to be drawn from this experience about the optimal design and operation of fixed exchange rate systems? The circumspect answer is none. It is hard to imagine any fixed-rate system that could have withstood a disturbance on the scale of the Great Depression. At the risk of being inadequately circumspect, I would suggest three lessons. First, the sustainability of fixed rate regimes rests on the credibility of policymakers' commitment to the system. If policymakers harbor reservations about the tradeoffs between exchange rate targets and other objectives, speculative pressures are sure to force the issue. Second, a fixed rate system does not obviate the need for international policy coordination.29/ To the contrary, policy coordination is integral to the successful operation of fixed-rate systems. Third, the composition of international reserves is more than a technical detail in the design of fixed-rate systems. The stability of such systems may hinge on the adequacy of the reserve-supply mechanism.

The circumspect answer is predicated, implicitly, on the assumption that the Depression was exogenous to the operation of the international monetary system. It is to this assumption that I now turn. 


\section{The Role of the International Monetary System in the Great Depression}

Imagine that a group of countries are subjected to a deflationary shock. For present purposes, it is largely irrelevant whether the initial disturbance is real or monetary. If it is monetary, real variables like output and employment follow money and prices down. If it is real, the quantity of money contracts as the demand for it declines. The critical question is what options are available to the central banks of the countries affected. If the exchange rate was of no concem, any one central bank could unilaterally initiate expansionary open market operations to stem the contraction of money supply. If central banks were committed to the maintenance of fixed exchange rates, it would be possible to initiate an internationally coordinated expansion of money supplies, arranged in such a way that no one exchange rate suffered undue weakness. But with a commitment to fixed rates and absent cooperation, reflationary action would be constrained.

Expansionary open market operations or discount rate reductions would lead to a rise in imports, a capital outflow, a loss of reserves and, ultimately, an attack on the exchange rate.

The same external constraints would limit the use of fiscal policy. Except in the presence of high international capital mobility, and asset substitutability, a unilateral increase in deficit spending weakens the exchange rate. By raising spending on imports and crowding out exports, it leads to a current account deficit, a loss of reserves and, ultimately, an attack on the exchange rate. Under such circumstances, a commitment to a fixed exchange rate requires that any significant fiscal expansion be coordinated internationally. 30 /

This is the principal channel through which the gold exchange standard exacerbated the Great Depression. Given fixed rates, reflation required cooperation. Absent cooperation, reflation was impossible.

This thesis assumes that the effects of the international monetary system came into play only following the initial shock. The international monetary system contributed to the depth and duration of the Great Depression rather than to its onset. One can construct an argument under which the same constraints contributed to the Depression's onset. For example, Hamilton (1987) argues that tight monetary policy in the United States played an important role in the onset of the Depression. Tight monetary policy also contributed to America's payments surpluses and to incipient reserve losses abroad, 
forcing other countries such as Britain and Germany to raise their discount rates in the first half of 1929. But the explanation for the onset of the Depression remains too controversial for this to be more than speculation.

In addition, the thesis assumes that gold standard countries maintained an unbending commitment to their fixed exchange rates. Reality was more complex. Once forced from the gold standard, countries like Britain luxuriated in their newfound freedom, adopting policies of cheap money and allowing their exchange rates to fall as needed rather than repegging at a lower parity. Others like Germany maintained the pretence of a fixed exchange rate but adopted exchange controls that were tantamount to depreciation. Still others like Sweden took Britain's devaluation as an opportunity to reject the gold standard in favor of cheap money and a depreciated exchange rate. But fixed exchange rates remained a constraint for virtually every industrial country until the final months of 1931 and, for a significant subset of countries, for several subsequent years. Recognition that the exchange rate constraint might be incompatible with recovery only took shape in the U.S. in 1933, in Belgium in 1935, and in France, the Netherlands and Switzerland in 1936.

Several factors explain this commitment. The gold standard was viewed as synonymous with financial stability, and financial stability was viewed as necessary for economic recovery. Financial centers like London, New York, Amsterdam and Switzerland saw the maintenance of fixed rates as essential to their ability to compete successfully in the financial services industry. In countries like France and Belgium, which had suffered persistent inflation in the 1920s, the public associated depreciation with inflation and social chaos, and politicians sought to resist it at any cost.

Finally, the thesis stated above assumes that the intemational coordination of reflationary initiatives proved impossible to achieve. Although it was suggested on more than one occasion that international coordination of policies could relax the external constraint, efforts at implementation proved unavailing. In 1930-31, Keynes urged the Bank of England to expand, in the hope that it could induce the Fed to follow. The British Treasury unsuccessfully pressured the Bank of France to expand. In 1933, at the World Economic Conference, it was the hope of a number of national delegations that a program of internationally coordinated reflation could be adopted.31/ There is no simple explanation for the failure of these initiatives. Some governments were beholden to the fallacious view that adherence to the gold standard obviated the need for cooperation. 
The standard model of the gold standard was one of a homeostatic system, with every boat floating on its own bottom. Efforts to coordinate policies were greatly complicated by the overhang of war debts and reparations. Sectoral interests blocked concessions which foreign countries would have required in return for monetary cooperation.32/

The external constraint was binding in significantly more instances than standard accounts of the period allow. The Bank of England was constrained in its efforts to expand in 1930 and 1931. The Reichsbank was prevented from expanding in the spring of 1931 , when its reserves fell to their statutory minimum. Only with the help of window dressing and a transfer of deposits by the Bank of England did it manage to obey the letter of the gold standard law. The National Bank of Belgium attempted a more expansionary policy in August 1934. This led to a loss of reserves which forced retrenchment, exchange control and finally devaluation.33/

More significant still was the extent to which the Federal Reserve and the Bank of France, the two central banks with the strongest reserve positions, were inhibited by the external constraint. The Fed was forced to raise its discount rate, more quickly than ever before in its short history, in the final months of 1931, when the devaluation of sterling increased the perceived riskiness of foreign dollar balances. Fearful of the implications of gold outflows for the defensibility of the exchange rate, the Fed limited its open market purchases of securities to a modest $\$ 50$ million in a period when M2 was falling by more than $\$ 1$ billion. Friedman and Schwartz (1963) criticize the Fed for worsening the Depression, but it is unclear what else a central bank committed to the gold standard parity could have done. Similarly, when in the spring of 1932 the Fed initiated large-scale open market purchases, the gold losses to which the program led quickly caused its abandonment.34/ There is considerable debate over the realism of the Fed's fears, on both occasions, that gold losses threatened an exchange-rate crisis. But there is no question that the fear profoundly influenced policymaking.

In France, developments followed a similar course, although they evolved more slowly. Policy ran up against the external constraint starting in 1934. The Flandin Government which came to power in November 1934 attempted to reflate and at the same time to maintain the gold parity. The cornerstone of its program was a more liberal credit policy. The Bank of France was encouraged to discount Treasury bills on behalf of the fiscal authorities, whose budget was in substantial deficit. Predictably, the program led to a deterioration in the external accounts: the Bank of France lost 2 per 
cent of its reserves in May 1935 and an alaming 11 per cent in june. The centrai bank was forced to raise its discount rate from $21 / 2$ to 6 per ceni, and the Flandin Government fell.35/ The Laval Government which eventuilly replaced it reverted to deflationary policies. But as opposition to its austerity measures mounted, it too reversed course. Rather than pushing for further cuts in the public spending, it induced the Bank of France to again begin discounting treasury bills as required to finance the budget deficit. The drain of reserves from the central bank accelerated. In April and May of 1936, the Bank of France lost 9 per cent of its reserves. Once again it became clear that the conflict between reflation and the external constraint was fundamental. The difference was that by 1936 opposition to deflation had finally boiled over. Laval's difficulties contributed to the victory of the Popular Front in the spring 1936 elections. A new reflationary program was adopted. When its operation again compelled the authorities to choose between abandoning their recovery program and devaluing the currency, this time they opted for the latter.

Thus, fixed exchange rates represented a binding constraint on recovery policies even for the countries with the strongest reserve positions.

It was not only as a limit on the ability to adopt policies of cheap money and deficit spending, like those of Britain and Sweden, respectively, that the effects of the external constraint were felt. The exchange-rate constraint also limited the ability of central banks to insure the stability of banking systems. Several explanations for the depth and persistence of the Great Depression revolve around banking panics and their consequences. Friedman and Schwartz (1963) argue that bank failures induced a shift out of deposits and into currency; the consequent decline in money supply depressed output and prices. Bernanke (1983) argues that bank failures interrupted the provision of financial services; disintermediation disnupted resource allocation and depressed economic activity. Both sets of authors focus on the United States. But the phenomenon was quite general. In Austria, Germany, Hungary, Belgium and still other countries, similar financial difficulties arose. In each case, banking panics led to further deterioration of an already critical economic situation.

Unfortunately, none of these authors places sufficient weight on the role of the exchange rate constraint in the banking panics. Stemming a run on the banks would. have required intervention by the lender of last resort. Only by affirming its willingness to provide emergency liquidity to the banking system, and backing its words with deeds, 
could central banks have contained bank runs. But a rapid increase in domestic credit threatened to produce a loss of international reserves. For central banks whose reserves were at the statutory minimum, this would have represented a breach of the gold standard statutes and a fatal blow to confidence in the exchange rate. Moreover, domestic bank runs tended to undermine exchange rate stability directly, even in the absence of central bank intervention. Foreign depositors who ran on domestic banks repatriated their funds. Domestic depositors concerned about financial stability moved hheir money abroad. The actions of both sets of agents produced a capital outflow and a decline in central bank reserves. For monetary authorities whose priority was defense of the exchange rate, this was the worst possible moment to expand the supply of domestic credit.

When panics erupted, therefore, the response of central banks tended to be hesitant and delayed. In Germany, the losses suffered by the big industrial banks became known at the end of 1930. But rather than injecting reserves into the system to bolster confidence, the Reichsbank stood idly by. When the situation reached crisis proportions, the Reichsbank's cover ratio had fallen to 40.1 per cent, barely above the statutory 40 per cent minimum. To defend its foreign reserves, the Reichsbank was forced to maintain a high discount rate and to ration credit. With the hands of the lender of last resort firmly tied, the smallest shock could topple the banking system. It took the form of the failure of the Nordwolle textile firm, which led to a run on the Darmstadter Bank, the Nordwolle's leading creditor.

A similar story can be told for a number of other countries. The gold standard constraints even came into play in the United States. The second wave of bank failures in the U.S. arose in August-September 1931, when uncertainty about the fate of sterling was at its height. The question of why the Fed did not intervene more aggressively is easily answered: fear for the gold parity. The gold cover ratio was not an immediate problem, but the drain of reserves -- 12 per cent between September and November -was disquieting. Moreover, there was the problem of free gold: the Fed was required to hold not only a gold cover of 40 per cent against Federal Reserve notes, but the other 60 per cent had to take the form of gold or eligible securities (essentially excluding government bonds). Thus, the Fed could engage in open market purchases of government bonds only to the extent of its free gold, which had fallen to about $\$ 800$ million in the wake of Britain's devaluation,36/ This left some room for maneuver, 
although the Fed wished to prevent free gold from falling to zero, at which point it would be totally incapable of sterilizing the effects of reserve outflows. One can argue that the Fed made the wrong choice by failing to intervene more aggressively; but there is little question that the gold standard figured prominently in its decision.

By 1933, the Glass-Steagall Act had relaxed the free gold constraint. But the statutory gold cover ratio of 40 per cent remained. When an even more serious wave of bank failures erupted in the early months of 1933, again the Fed was restrained from responding aggressively by the need to defend the exchange rate. As in Germany in 1931, bank failures led to the liquidation of foreign deposits and to a capital outflow. Sterling and other currencies rose relative to the dollar. The balance of gold imports and exports swung from surplus to deficit between Febriary and March. Gold placed under earmark rose dramatically. For the week ending March 1st, the Fed lost $\$ 116$ million in gold due to earmarking. On March 3rd alone, $\$ 109$ million worth was placed under earmark in New York.37/ These numbers were small compared to a gold reserve of some $\$ 4$ billion, and the gold reserve still amounted to 45 per cent of the deposit and note liabilities of the Federal Reserve banks on March 3rd. But the trend was clear. Moreover, by this time it is no longer appropriate to argue that causality ran unidirectionally from the banking panic to the foreign exchange market. There were apprehensions about President-Elect Roosevelt's commitment to the dollar parity, and foreigners began to withdraw their deposits from the United States in response to the possibility of devaluation as well as the instability of the banking system. But so long as the gold standard constraint remained in force, doubts about its sustainability only reinforced the pressure on the Fed. With the cover ratio falling toward the statutory minimum, the central bank felt that there was little scope to inject liquidity into the collapsing banking system.

The point can be driven home by considering a country off the gold standard, in which the response to a potential banking panic was very different. The suicide of Ivar Krueger, the Swedish industrialist and financier, in March 1932, following revelations of financial fraud, raised doubts about the solvency of Krueger's banker, the Skandinaviska Kreditaktiebolag. But having devalued in 1931, the Riksbank was free to intervene. It conducted some 200 million kronor's worth of expansionary open market operations in response to the Krueger crisis. A banking panic was not allowed to delay Sweden's recovery from the Depression. 
In much of the literature, the gold standard is portrayed as synonymous with financial stability. In the 1930 s, as this account should make clear, the opposite was true. Far from synonymous with stability, the decentralized gold exchange standard directly threatened financial stability between the wars.

Having analyzed channels through which the international monetary system contributed to the Depression, it is useful to mention some through which it did not. The competitive depreciation of currencies, often blamed for worsening the Depression, had on balance a salutary effect.38/ Elimination of the gold standard constraint permitted monetary policy to be enlisted on behalf of economic recovery. This package of policies accelerated recovery in devaluing countries through several complementary channels: promoting exports, raising prices relative to costs, permitting interest rates to be reduced, raising real share prices, and stimulating investment. Admittedly, devaluation was beggar-thy-neighbor, but these beggar-thy-neighbor effects could have been eliminated had countries which remalned on gold emulated those which devalued. At worst, devaluation redistributed the Depression internationally. Insofar as it facilitated monetary expansion in at least some countries, it accelerated the recovery. My reading of the evidence is contrary to the view that devaluation did nothing for the initiating countries and only damaged their trading parners.

The uncoordinated way in which devaluation took place was not optimal. It created needless uncertainty. It encouraged the liquidation of foreign exchange reserves. The possibility of unilateral devaluation induced central banks to liquidate their foreign deposits. Insofar as they sought to replace those foreign exchange reserves, gold had to be acquired from abroad. To do so, central banks raised their discount rates, creating another competitive, mutually-defeating scramble for gold like that of the 1920s. Those higher discount rates and more stringent domestic monetary conditions could have given the Depression another fillip. But in fact, the increase in global gold demand was minimal.39/ In part, central banks simply liquidated their excess foreign exchange reserves. More importantly, devaluing countries could reduce their reserve ratios. The liquidation of foreign exchange reserves and the induced increase in discount rates in gold standard countries magnified devaluation's beggar-thy-neighbor effects. But there is no evidence that they eliminated its benefits,

There is another important caveat to the view that compeditive depreciation was benign. Uncoordinated, haphazard devaluation contributed to the destruction of trade. 
Gold standard countries imposed exchange-dumping duties against goods exported by devaluing countries. Even countries with depreciated currencies imposed new tariffs against other producers off gold. As a result, the volume of trade recovered more slowly in the 1930s than the volume of domestic production. The implication is that international policy coordination, which would have minimized the likelihood of retaliation, would have been as advantageous following the gold standard's collapse as during its operation.

\section{Conciusion and Summary of Implications}

Interwar experience underscores the difference the exchange rate system can make. It confirms the generality of several widely held interpretations of recent experience with floating. There is a positive association between nominal exchange rate flexibility and nominal exchange rate variability. There is a positive association between nominal exchange rate variability and real exchange rate variahility. But policies of intervention which reduce nominal exchange rate variability do not guarantee a proportionate reduction in nominal exchange rate risk or in real exchange rate variability and predictability. A credible commitment to a stable intervention rule -- including but not limited to a commitment to peg the nominal rate -- is needed to deliver these benefits.

Interwar experience also suggests what is needed to render such a commitment credible. It verges on the tautological to remind the reader that credibility, in this instance, requires of policymakers that they attach a heavy weight to exchange rate stability relative to other targets. So long as other targets retain a nonnegligible weight, major disturbances affecting those targets can still raise questions about operational implications of policymakers' commitment to the exchange rate. But the credibility of the commitment can be greatly enhanced by international policy coordination. In the interwar period at least, policy coordination could have significantly relieved the conflict between the commitment to fix the exchange rate and the commitment to other targets.40/ Far from a surrogate for policy coordination, the desire to maintain a system of stable exchange rates rendered the need for coordination all the more pressing. 


\section{FOOTNOTES}

1. While generally the case, this response by the belligerents was not universal. Great Britain, for example, nominally retained convertibility throughout the war, although moral suasion and bureaucratic impediments discouraged residents who might have wished to exchange domestic currency for gold. Most of the neutrals, for whom the problem was gold inflows rather than outflows, also retained official convertibility, although they pursued various policies designed to discourage attempts to obtain domestic currency for gold.

2. In the case of France, this refers to de facto stabilization of the franc. Although the franc remained stable from December 1926, de jure stabilization only followed in June 1928.

3. Estimates of the currency composition of reserves prior to 1913 are provided by Lindert (1969).

4. The negotiations surrounding the French devaluation, which led to the Tripartite Agreement signed by Britain, France and the U.S., are interesting in their own right and for their implications for the subsequent course of exchange rates. These matters, which are discussed in Eichengreen (1985), are beyond the scope of the present paper.

5. Two studies which examine the British case in detail are Hall (1935) and Howson (1980). The operations of other equalization funds are analyzed by Nurkse (1944).

6. This is the assertion of Kindleberger (1973), which has gained considerable currency.

7. I limit my analysis of the flexible-rate period to $1922-26$ in order to maximize comparability across tables. This periodization makes little if any difference for the results, as I indicate below.

8. For the $1930 \mathrm{~s}$ it is also possible to compute trade-weighted effective exchange rates. These behave in similar fashion. See Eichengreen (1989a).

9. The horizontal lines in Figure 2 for Germany in the 1930 s reflect missing data.

10. When the sample is extended backwards by a year and the periods 1921-26 and 1932-36 are compared, the average variability of the spot rate (Germany excluded) falls by 48 per cent, while the average risk premium falls by 40 per cent. A more sophisticated measure of the risk premium would subtract from the forward rate not the realized future spot rate but a proxy for the expected future spot rate, perhaps constructed by projecting $S_{t+1}$ on information available at time $t$. I plan to pursue this line of inquiry in future work.

11. The differential rises to 136 per cent when Germany is included.

12. This remains true for the early 'twenties when the German outlier is excluded. A more demanding test of the significance of the association between real and nominal exchange rate variability is the rank sum statistic testing the hypothesis that real and nominal rates are drawn from distributions identical but for their medians. According to 
this statistic, the null hypothesis cannot be rejected for the early 'thirties at the 95 per cent level and for the early 'twenties at the 90 per cent level.

13. This is somewhat more general than previous analyses, such as Rogoff (1985a) and Artis (1987), which construct the forecast on the assumption that the exchange rate follows a random walk with no drift. The regression coefficients underlying the forecasts are reported in the appendix tables. In most cases, it is impossible to reject the random walk hypothesis, however. In Eichengreen (1989a) I also estimate forecasting equations using a more general ARMA model and compute the same summary statistics. In future work, I plan to estimate forecasting equations that include also other information, such as lagged money and lagged prices.

14. In Eichengreen (1988a) I documented the strong positive correlation between the variability of real and nominal exchange rates within both periods. The present result, for the correlation between the variability of real and nominal exchange rate forecast errors within both periods, is suggestive of stronger welfare implications.

15. If we regress the sample average real exchange rate forecast error on the nominal exchange rate forecast error (and a constant term) for each cross section of 10 countries (Germany excluded), we can reject the hypothesis of no association at the 99 per cent confidence level for the early 'twenties and at the 95 per cent confidence level for the early 'thirties.

16. The classic account of the period emphasizing these terms of trade disturbances is Lewis (1949). The regression coefficients underlying the real exchange rate forecasts are provided in Table A2.

17. Industrial production indices are drawn from the League of Nations' Statistical Bulletins, as supplemented by Thorp (1984) and Hilgerdt (1945).

18. A similar analysis of post-World War II data has been carried out by Baxter and Stockman (1988).

19. Nurkse (1944), pp. 69.

20. Studies which adopt this approach using time series data for Great Britain are Goodhart (1972) for the pre-1914 period and Eichengreen, Watson and Grossman (1985) for 1925-31. Roubini (1988) has shown that the standard interpretation is consistent with a model of an optimizing central bank. In response to most shocks, a central bank concerned mainly with domestic conditions (specifically, the stability of domestic interest rates) will adopt policies which result in negative comovements of domestic and foreign assets. Positive comovements will be observed if there is a relatively high weight on external targets (specifically, the stability of the level of reserves) in the central bank objective function.

21. The change in domestic and foreign assets is taken from Nurkse (1944), Appendix 1 , and from the League of Nations' Monetary Reviews. The equations are estimated using ordinary least squares. This creates potential problems of endogeneity bias, given the fact that foreign reserves are likely to respond to domestic open market operations through the balance of payments. I plan to attempt corrections for this in future work. 
22. Even then, the stability of the international monetary system depended on other special factors, including the maintenance of inconvertibility as late as 1958 . I evaluate the applicability of hegemonic stability theories to this experience in Eichengreen (1989b).

23. The New York Fed cooperated by lowering its discount rate, obviating the need for the Bank of England to raise its rate. Thus, the pressure on sterling was ameliorated without a rise in interest rates at a time when the world economy was poised on the verge of recession. Those who follow Clarke interpret this as an example of cooperation (although it also might be interpreted as a purely self-interested action by a Fed alarmed by the danger of an American recession).

24. Kindleberger (1973), pp. 298-299.

25. Keynes (1929), pp. 778-779.

26. An explicit model which demonstrates circumstances under which these results obtain is sketched in Eichengreen (1985).

27. Two clear if skeptical formulations of this hypothesis are Mlynarski (1929, pp. 75-76) and Nurkse (1944, p. 44).

28. What mattered for the stability of the international monetary system was not that central banks liquidated their foreign exchange reserves, but that they attempted simultaneously to replace them with gold. Given the limited availability of monetary gold in the world economy, this could be accomplished only by increasing discount rates, tightening credit conditions and attempting to acquire specie from abroad, the consequence of which was to intensify the pressure on weak currency countries. See Eichengreen (1988b).

29. The idea that fixed rates can function as surrogates for intemational policy coordination has been argued by Canzonari and Gray (1985), albeit in what they admit is a special case.

30. Sachs and Wyplosz (1984) show how the substitutability of domestic and foreign goods in consumption, the substitutability of domestic and foreign assets in portfolios, and the degree of international capital mobility interact to produce different exchange rate effects of fiscal policy. Surely most observers would agree that the case discussed in the text is the one relevant to the 1930s.

31. Keynes's efforts to influence policy in 1930-31 are analyzed in Cairncross and Eichengreen (1983), pp. 59-61. Anglo-French discussions are recounted in Eichengreen (1986). A good summary of the World Economic Conference is provided by Kindleberger (1973), chapter 9.

32. For example, at the 1933 World Economic Conference France requested that the U.S. and Britain stabilize their exchange rates and that the three countries adopt a coordinated program of reflationary policies. But already having gone off the gold standard, the U.S. and Bricain could reflate unilaterally. And France could offer little in 
return for a commitment by the U.S. and Britain to stabilize and coordinate. In principle, the French could have offered tariff reductions, but these were blocked by a domestic agricultural lobby which would have been adversely affected. Jackson (1985), p. 69.

33. van der Wee and Tavernier (1975), pp. 275-276.

34. Although there exist competing interpretations (see Epstein and Ferguson, 1984), I find the Fed's loss of reserves the most compelling explanation for the suspension of expansionary open market operations in 1932.

35. Sauvy (1984), pp. 162-171.

36. The account I offer here conflicts with that of Friedman anc Schwartz (1963), who deny that the Fed was consuained by the gold standard or by the probiem of "free goid."

37. These estimates are drawn from Hodson $(1938$, p. 211) and Nadler and Bogen (1933), p. 155.

38. Having belabored this point on more than one occasion, I provide only the briefest summary here. For a complete analysis, see Eicherigreen and Sachs (1985).

39. Regression evidence and a more elaborate version of the argument are presented in Eichengreen (1988b).

40. Rogoff (1985b) has constructed an example where policy coordination can reduce credibility by exacerbating the time consistency problem facing policymakers. The statement in the text reflects my belief that this case has little applicability to the episodes with which this paper is concemed. 


\section{REFERENCES}

Artis, M.J. (1987), "The European Monetary System: An Evaluation," Journal of Policy Modeling 9, pp. 175-198.

Baxter, Marianne and Alan Stockman (1988), "Business Cycles and the Exchange Rate System: Some International Evidence," NBER Working Paper No. 2689 (August).

Bernanke, Ben (1983), "Nonmonetary Effects of the Financial Crisis in the Propagation of the Great Depression," American Economic Review 73, pp. 257- 276.

Bloomfield, Arthur (1959), Monetary Policy Under the International Gold Standard: 1880-1914, New York: Federal Reserve Bank of New York.

Cairncross, Alec and Barry Eichengreen (1983), Sterling in Decline, Oxford: Blackwell.

Canzonari, Matt and JoAnna Gray (1985), "Monetary Policy Games and the

Consequences of Noncooperative Behavior," International Economic Review 26, pp. 547 564.

Clarke, S.V.O. (1967), Central Bank Cooperation. 1924-1931, New York: Federal Reserve Bank of New York.

Eichengreen, Barry (1985), "International Policy Coordination in Historical Perspective: A View from the Interwar Years," in Willem Buiter and Richard Marston (eds), International Economic Policy Coordination, Cambridge: Cambridge University Press, pp. 139-178.

Eichengreen, Barry (1986), "The Bank of France and the Sterilization of Gold, 1926-1932," Explorations in Economic History 23, pp. 56-84.

Eichengreen, Barry (1988a), "Real Exchange Rate Behavior Under Alternative Intemational Monetary Regimes: Interwar Evidence," European Economic Review 32, pp. 363-371.

Eichengreen, Barry (1988b), "Did International Economic Forces Cause the Great Depression?" Contemporary Policy Issues IV, pp. 90-113.

Eichengreen Barry (1989a), "The Comparative Performance of Fixed and Flexible Exchange Rate Regimes: Interwar Evidence," Prepared for the International Economic Association Conference, Copenhagen, June.

Eichengreen, Barry (1989b), "Hegeinonic Stability Theories of the International Monetary System," in Richard Cooper, Barry Eichengreen, Randall Henning, Gerald Holtham and Robert Putnam, Can Nations Agree? Issues in International Economic Cooperation, Washington, D.C.: The Brookings Institution.

Eichengreen, Barry and Jeffrey Sachs (1985), "Exchange Rates and Economic Recovery in the 1930s," Journal of Economic History XLV, pp. 925-946. 
Eichengreen, Barry, Mark Watson and Richard Grossman (1985), "Bank Rate Policy Under the Interwar Gold Standard: A Dynamic Probit Model," Economic Journal 95, pp. 725-745.

Einzig, Paul (1937), The Theory of Forward Exchange, London: Macmillan.

Epstein, Gerald and Thomas Ferguson (1984), "Monetary Policy, Loan Liquidation and Industrial Conflict: The Federal Reserve and the Open Market Operations of 1932," Journal of Economic History XLIV, pp. 957-984.

Friedman, Milton (1953), "The Case for Flexible Exchange Rates," in Essays in Positive Economics, Chicago: University of Chicago Press.

Friedman, Milton and Anna Schwartz (1963), A Monetary History of the Unites States. 1867-1960, Princeton: Princeton University Press.

Goodhart, C.A.E. (1972), The Business of Banking, London: Weidenfeld and Nicolson.

Hall, N.F. (1935), The Exchange Equalisation Account, London: Macmillan.

Hamilton, James (1987), "Monetary Factors in the Great Depression," Joumal of Monetary Economics 13, pp. 1-25.

Hilgerdt, Folke (1945), Industrialization and Foreign Trade, Geneva: League of Nations.

Hodson, H.V. (1938), Slump and Recovery, 1927-1937, London: Oxford University Press.

Howson, Susan (1980), "Sterling's Managed Float: The Operation of the Exchange Equalisation Account," Princeton Studies in International Finance no. 46, Princeton: Princeton University Press.

Jackson, Julian (1985), The Politics of Depression in France 1932-1936, Cambridge: Cambridge University Press.

Keynes, John Maynard (1925), The Economic Consequences of Mr. Churchill, New York: Harcourt Brace.

Keynes, John Maynard (1929), "Is There Enough Gold? The League of Nations Inquiry," in The Collected Writings of John Maynard Keynes. Volume XIX; Activities. 1922-1929: The Retum to Gold and Industrial Policy (ed. Donald Moggridge), New York: Cambridge University Press, pp. 775-780.

Kindleberger, Charles (1973), The World in Depression, 1929-1939, Berkeley: University of California Press.

League of Nations (various issues), Monthly Statistical Bulletin, Geneva: League of Nations. 
League of Nations (various issues), Monetary Review, Geneva: League of Nations.

League of Nations (various issues), Public Finances, Geneva: League of Nations.

Lewis, W. Arthur (1949), Economic Survey 1919-1939, London: Allen \& Unwin.

Linder, Peter (1969), "Key Currencies and Gold, 1900-1913," Princeton Studies in

International Finance no: 24, Princeton: Princeton University Press.

Mlynarski, Feliks (1929), Gold and Central Banks, New York: Macmillan.

Nadler, Marcus and Jules I. Bogen (1933), The Banking Crisis, New York: Dodd, Mead \& Co.

Nurkse, Ragnar (1944), International Currency Experience, Geneva: League of Nations.

Rogoff, Kenneth (1985a), "Can Exchange Rate Predictability Be Achieved without Monetary Convergence? Evidence from the EMS," European Economic Review 28, pp. 93-116.

Rogoff, Kenneth (1985b), "Can International Monetary Policy Coordination Be Counterproductive?" Joumal of International Economics 18, pp. 199-217.

Roubini, Nouriel (1988), "Offset and Sterilization Under Fixed Exchange Rates with an Optimizing Central Bank," NBER Working Paper no. 2777 (November).

Sachs, Jeffrey and Charles Wyplosz (1984), "Real Exchange Rate Effects of Fiscal Policy," Harvard Institute of Economic Research Discussion Paper 1050 (April).

Sauvy, Alfred (1984), Histoire economique de la France entre les deux guerres, Paris: Economica (second edition).

Thorp, Rosemary (1984), Latin America in the 1930s, London: Macmillan.

Triffin, Robert (1960), Gold and the Dollar Crisis, New Haven: Yale University Press.

van der Wee, Herman and K. Tavemier (1975), La Banque Nationale de Belgique et l'histoire monetaire entre les deux guerres mondiales, Brussels: Banque Nationale de Belgique. 